\title{
Ancyrocephalidae (Monogenea) of Lake Tanganyika: I: Four new species of Cichlidogyrus from Ophthalmotilapia ventralis (Teleostei: Cichlidae), the first record of this parasite family in the basin
}

\author{
Maarten P. M. Vanhove ${ }^{1,3}$; Filip A. M. Volckaert ${ }^{1} \&$ Antoine Pariselle $^{2}$ \\ 1 Laboratory of Animal Diversity and Systematics, Biology Department, Katholieke Universiteit Leuven, Charles Deberiotstraat \\ 32, B-3000 Leuven, Belgium. \\ ${ }^{2}$ IRD (ex-ORSTOM)/ISE-M, UR226/UMR5554, Université Montpellier II - CC 063, 34095 Montpellier Cedex 5, France. \\ ${ }^{3}$ Corresponding author. E-mail: maarten.vanhove@bio.kuleuven.be
}

\begin{abstract}
Examination of gill parasites from Ophthalmotilapia ventralis (Boulenger, 1898) in Lake Tanganyika (Africa) revealed the presence of four new species of Monogenea, all members of Cichlidogyrus Paperna, 1960 (Ancyrocephalidae). In view of the systematic importance of haptoral structure, the fish host shows a remarkable diversity of morphological groups. Cichlidogyrus vandekerkhovei sp. nov. and C. makasai sp. nov. are especially characterized by the unusual length of the dorsal transverse bar auricles, while C. sturmbaueri sp. nov. is distinguished by the unique shape of the accessory piece of its male copulatory organ. Importantly, C. centesimus sp. nov. displays a number of features new to the genus, namely a spirally coiled thickening at the end of the penis, the absence of an accessory piece in the genital apparatus, and a hitherto unknown uncinuli configuration in the haptor. This is the first record of ancyrocephalid parasites from the Tanganyika basin. Some mechanisms possibly contributing to this yet unknown diversity are discussed, identifying topics deserving further scientific scrutiny.
\end{abstract}

KEY WORDS. Cichlidogyrus vandekerkhovei sp. nov.; Cichlidogyrus makasai sp. nov.; Cichlidogyrus centesimus sp. nov.; Cichlidogyrus sturmbaueri sp. nov.; Africa.

Of the three major African Great Lakes (Malawi, Victoria and Tanganyika) Lake Tanganyika is the deepest and the oldest (CoHen et al. 1997). This lake is home to the most morphologically and genetically diverse fauna of Cichlidae in the world (Galis \& Metz 1998, SnOeKs 2000). For non-cichlids, the level of endemicity and the extent to which they evolved into species flocks is highest in this lake (SNOEKS 2000, SAlZbUrger et al. 2002). The lake harbours species flocks that result from radiations of several other fish families, such as Mochokidae (DAY \& WILKINSON 2006, КовLmüller et al. 2006) and Mastacembelidae (VReVen \& SNOEKS 2009, BRown et al. 2010). Various invertebrate taxa, among which platytelphusid crabs (MARIJNISSEN et al. 2006), Gastropoda (Michel et al. 2004, Wilson et al. 2004) and Ostracoda (MARTENS \& SCHÖN 1999, Wouters \& MARTENS 2001), also developed species flocks within Lake Tanganyika.

PolL (1986) classified the cichlids of Lake Tanganyika into tribes. One of which, the endemic and monophyletic tribe Ectodini, includes species that exhibit a wide range of choices in substrate and food items. Its 34 species, which are classified in 13 genera, are either biparental or maternal mouth-brooders (Konings 1998, TAKahashi 2003, Koblmüller et al. 2004, 2008, and references therein). Problems still exist regarding species identification and their respective taxonomical status (HANssEns et al. 1999). Among these, Ophthalmotilapia Pellegrin, 1904 is paraphyletic and needs taxonomic revision (KовLMÜLler et al. 2004). Ophthalmotilapia ventralis (Boulenger, 1898) and $O$. heterodonta (Poll \& Matthes, 1962) form a clade with Cyathopharynx furcifer (Boulenger, 1898), while O. boops (Boulenger, 1901) and O. nasuta (Poll \& Matthes, 1962) are sister taxa to each other.

However, despite the great number of studies on Cichlidae of Lake Tanganyika, studies on their parasite fauna, especially on their monogenean flatworms, are practically inexistent as in many tropical biomes throughout the world (WhitTINGTON 1998, BAKKe et al. 2002, HuYse et al. 2006, VANHOve et al. 2011). However, monogeneans are known to depict a considerable biological diversity - the average number of species per host is more than six in West Africa (Pariselle et al. 2003b) - and they usually depict high host specificity, parasitizing a single or few closely related host species. The high host specificity of monogenean species has recently been evidenced by the discovery of extensive cryptic speciation in the group (Pouyaud et al. 2006). Further evidence for the expected high host specificity is provided by the demonstration that the monogenean fauna may 
help understand the systematics, phylogeny and biogeography of their host groups (Euzet et al. 1989, GuÉGAN \& LAMBERT 1990, Paugy et al. 1990, Van Every \& Kritsky 1992, Nieberding \& Olivieri 2007, Plaisance et al. 2008, Barson et al. 2010).

So far, most species of Monogenea recorded from cichlids belong to Cichlidogyrus Paperna, 1960, with 71 currently described species (PARISElle \& EuZet 2009) mostly from West Africa, but also from South and East Africa and West Asia (Levant). Here, we describe the first representatives of the genus from the Tanganyika basin.

\section{MATERIAL AND METHODS}

Fish were caught in April 2008 (Zambia and Tanzania) and April 2010 (Democratic Republic of the Congo (DRC)) using gill or hand nets. Species were determined on site by C. Sturmbauer (Karl-Franzens University of Graz, Austria) and by R. Muzumani (Centre de Recherche en Hydrobiologie, Uvira, DRC). The fishes were dissected, as soon as possible, and the right branchial arches were stored in 96\% ethanol for further examination. Fish specimens were numbered, fixed, and preserved in ethanol for subsequent species determination. Additional parasite specimens were collected from $O$. ventralis hosts captured in Zambia in April 1995 and retrieved from the Royal Museum for Central Africa collections (MRAC 95-96-P296-301).

In the laboratory, the gills were transferred into clear water in a Petri dish and the monogeneans were detached from these gills using a strong water jet. The worms were individually transferred onto a slide with a mounted needle, directly into a drop of ammonium picrate-glycerine solution (prepared according to MALMBerg 1957), covered with a round cover slip, and sealed with Glyceel (BATEs 1997). Some worms from the DRC were mounted between slide and coverslip with Malmberg's solution in the field. Drawings of the sclerotised pieces of the haptor and of the copulatory complex were made using a Leica DM2500 microscope with a camera lucida and a video camera (Leica DFC320). Measurements were obtained with a Leica Application Software v 3.1 and are presented in micrometers with the mean followed by the range and the number of measurements in parentheses. All measurements follow Gussev (1962) (Fig. 1). The method of numbering the haptoral parts is that recommended in ICOPA IV (see EUzET \& Prost 1981); the terminology of structures follows Pariselle \& Euzet (1995b). PCA analysis was performed using Statistica v. 9 (StatSoft, Inc. 2009).
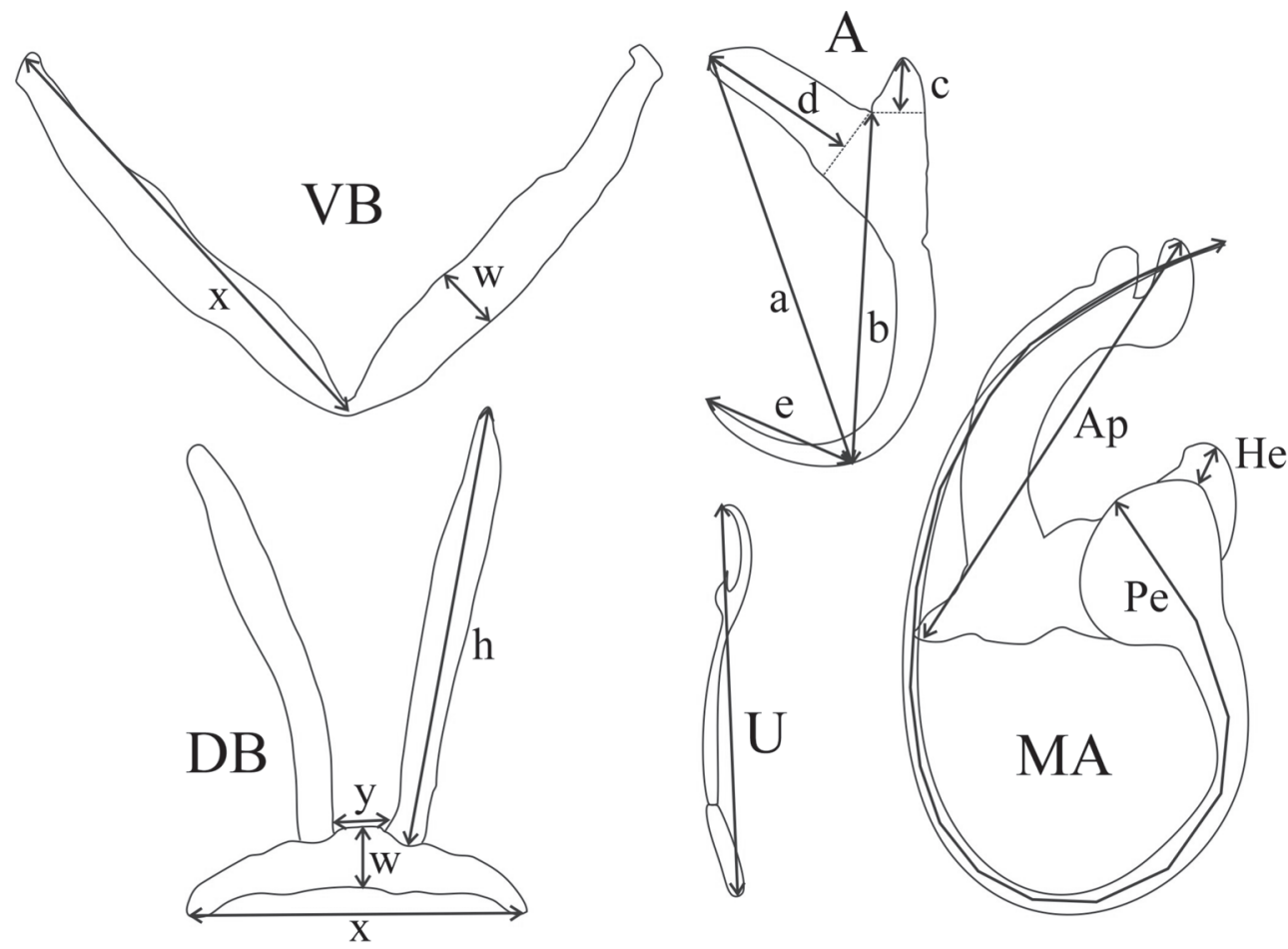

Figure 1. Measurements used in this study: (DB) dorsal transverse bar: (h) length of dorsal bar auricle; (w) dorsal bar maximum width; (x) dorsal bar total length; (y) distance between auricles; (A) anchor: (a) anchor total length; (b) anchor blade length; (c) anchor shaft length; (d) anchor guard length; (e) anchor point length; (MA) male apparatus: (Ap) accessory piece length; (Pe) penis total length; $(\mathrm{He})$ heel length; $(U)$ uncinuli length; $(V B)$ ventral transverse bar: $(w)$ ventral bar maximum width; $(x)$ length of one ventral bar branch. 


\section{TAXONOMY}

All four new species of Monogenea found on the gills of specimens of O. ventralis belong to Cichlidogyrus Paperna, 1960 (according to PAPERna 1960 and Pariselle et al. 2003a; it should be noted, however, that the absence of an accessory piece in the male copulatory organ (MCO) of C. centesimus sp. nov. might indicate the need for revision of the generic diagnosis). These species are described below.

\section{Cichlidogyrus vandekerkhovei sp. nov.}

Fig. 2

Type host: Ophthalmotilapia ventralis (Boulenger, 1898). Additional hosts: O. nasuta (Poll \& Matthes, 1962) and O. boops (Boulenger, 1901).

Site: gills.

Type locality: Wonzye Point $\left(8^{\circ} 43^{\prime} 30^{\prime \prime} \mathrm{S}, 31^{\circ} 8^{\prime} 0^{\prime \prime} \mathrm{E}\right)$ (Lake Tanganyika, Zambia).

Other records: also found on the type host at Kasenga Point $\left(8^{\circ} 43^{\prime} 31^{\prime \prime} \mathrm{S}, 31^{\circ} 8^{\prime} 1^{\prime \prime} \mathrm{E}\right)$ (Zambia) and at Kikoti $\left(7^{\circ} 11^{\prime} 27^{\prime \prime} \mathrm{S}\right.$, $30^{\circ} 4^{\prime} 0^{\prime \prime} \mathrm{E}$ ) (Democratic Republic of the Congo), and on O. nasuta and $O$. boops at Mtosi $\left(7^{\circ} 35^{\prime} 27^{\prime \prime}\right.$ S, 30 38'29"E) (Tanzania) (all in Lake Tanganyika).

Material studied: 20 individuals.

Type material: holotype deposited at the Muséum National d'Histoire Naturelle (Paris): HEL 191, Tf 210. Paratypes deposited at the Muséum National d'Histoire Naturelle (Paris): HEL 192, Tf 211; at the Royal Museum for Central Africa (Tervuren): 37675 and 37679; and at the Iziko South African Museum (Cape Town): SAMCTA 29504.

Description: Body $254(163-355, \mathrm{n}=20)$ long, 83 (69-112, $\mathrm{n}=20)$ wide at mid-body. Pharynx is $23(17-29, \mathrm{n}=9)$ wide. Dorsal anchor with very short shaft and more pronounced guard, blade arched, slightly bent in the middle: $\mathrm{a}=26(23-28, \mathrm{n}=28)$, $\mathrm{b}=21(19-23, \mathrm{n}=25), \mathrm{c}=2(1-4, \mathrm{n}=25), \mathrm{d}=8(5-10, \mathrm{n}=25), \mathrm{e}$ $=11(9-12, \mathrm{n}=28)$. Dorsal transverse bar straight or slightly arched, small, with extremely long auricles: $\mathrm{x}=23(20-27, \mathrm{n}=$ $20), y=4(2-6, n=20), w=4(3-5, n=20), h=30(24-34, n=36)$. Ventral anchor, with same shape as dorsal anchor: $\mathrm{a}=25$ (22-29, $\mathrm{n}=27), \mathrm{b}=20(17-26, \mathrm{n}=27), \mathrm{c}=(2-5, \mathrm{n}=27), \mathrm{d}=7(5-10, \mathrm{n}=$ $27), e=10(9-13, n=27)$. Ventral transverse bar V-shaped, often twisted: $\mathrm{x}=31(26-35, \mathrm{n}=20), \mathrm{w}=4(3-5, \mathrm{n}=20)$. Uncinuli I small $($ see Remarks below $)=12(11-14, \mathrm{n}=10)$ long; II $=11(9$ -

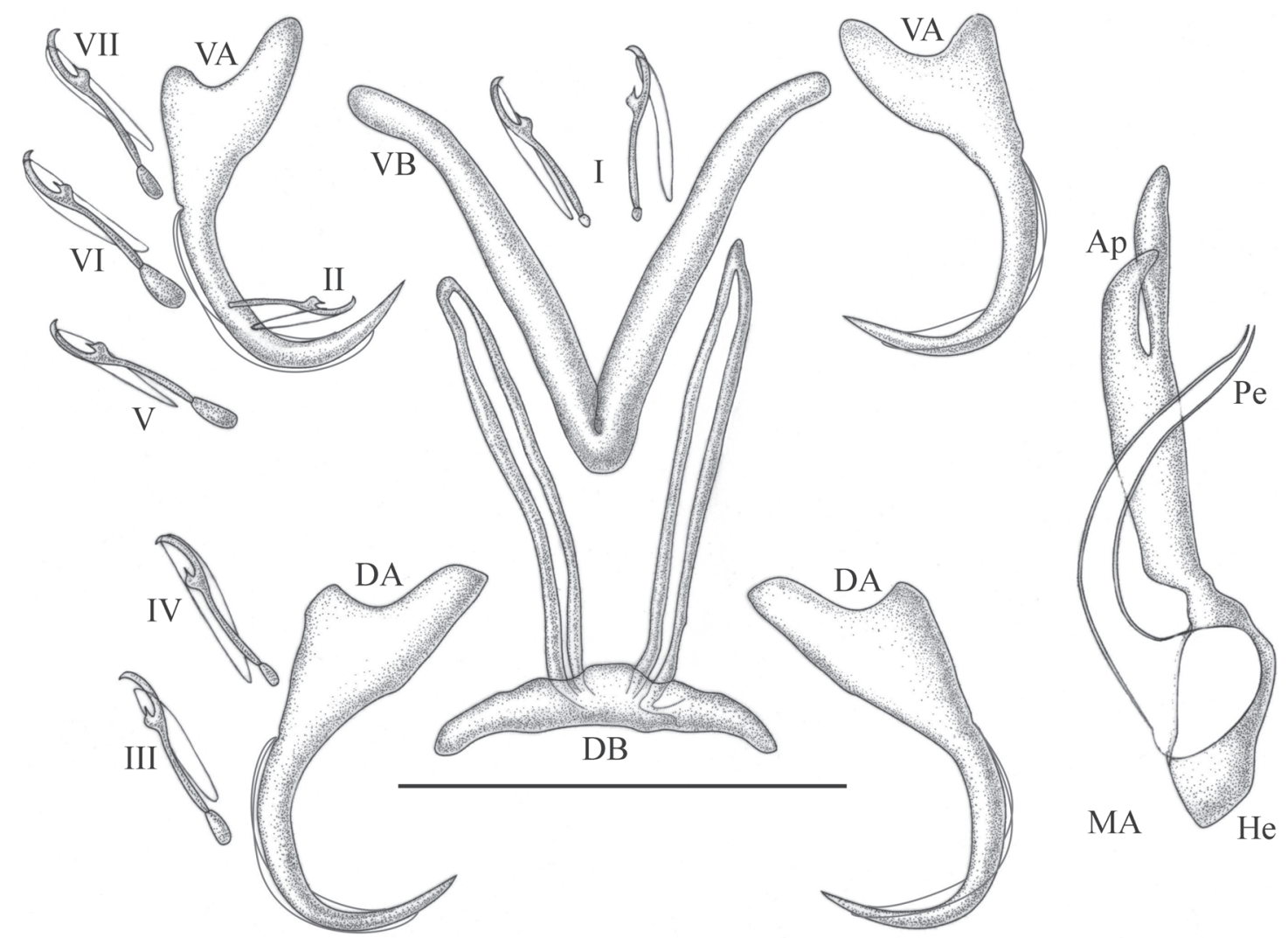

Figure 2. Cichlidogyrus vandekerkhovei sp. nov.: (Ap) accessory piece; (DB) dorsal transverse bar; (DA) dorsal anchor; (He) heel; (MA) male apparatus; (Pe) penis; (VB) ventral transverse bar; (VA) ventral anchor; (I-VII) uncinuli. Scale bar $=30 \mu \mathrm{m}$. 
$13, \mathrm{n}=15)$ long; III to VII short (see Remarks below) $=16(13-23$, $\mathrm{n}=67$ ) long. Penis, beginning in a large spherical bulb with well-developed heel, $\mathrm{He}=5(4-6, \mathrm{n}=20)$, a short and large curved tube of which the diameter narrows abruptly at the distal extremity: $\mathrm{Pe}=34(30-37, \mathrm{n}=20)$, simple and straight accessory piece with forked end, one extremity shorter than the other, sometimes crossed: Ap = 31 (24-34, n = 20). Vagina not observed.

Remarks. Despite the presence of very long auricles on the dorsal bar, similar in size to the auricles of species of Scutogyrus Pariselle \& Euzet, 1995 (see Fig. 3), C. vandekerkhovei sp. nov. is considered a representative of Cichlidogyrus. Indeed, Scutogyrus spp. have a characteristically enlarged dorsal bar and a thin oval plate associated to the ventral bar (PARISElle \& EuzET 1995a), which are not present in C. vandekerkhovei sp. nov.

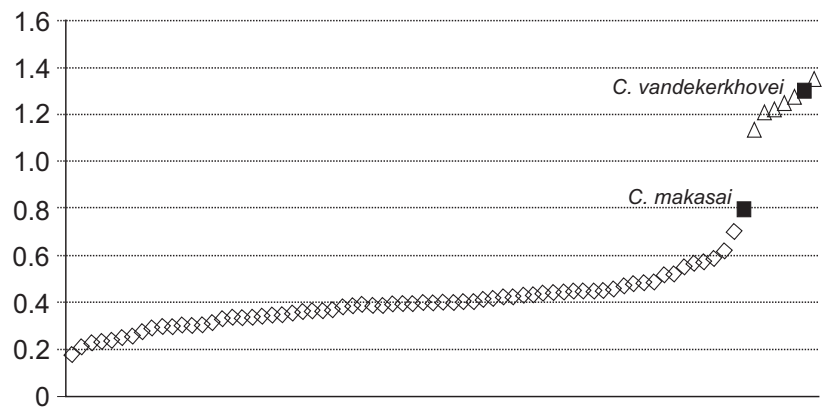

Figure 3. Length of dorsal-bar auricles/length of dorsal transverse bars in 67 Cichlidogyrus spp. $(\diamond), 6$ Scutogyrus spp. $(\triangle)$ and $C$. vandekerkhovei and C. makasai sp. nov. (ם).

The 71 species of Cichlidogyrus presently described from Africa and the Levant can be clustered in four morphological groups, according to the length of their uncinuli (Pouyaud et al. 2006, PARISELle \& EuZET 2009, Vignon et al. 2011). Cichlidogyrus vandekerkhovei sp. nov. belongs to the group with uncinuli I and III to VII short. This group includes: C. acerbus Dossou, 1982; C. amieti Birgi \& Euzet, 1983; C. amphoratus Pariselle \& Euzet, 1995; C. berrebii Pariselle \& Euzet, 1994; C. bifurcatus Paperna, 1960; C. cirratus Paperna, 1964; C. cubitus Dossou, 1982; C. fontanai Pariselle \& Euzet, 1997; C. giostrai Pariselle, Bilong Bilong \& Euzet, 2003; C. haplochromii Paperna \& Thurston, 1969; C. karibae Douëllou, 1993; C. lagoonaris Paperna, 1969; C. levequei Pariselle \& Euzet, 1996; C. longipenis Paperna \& Thurston, 1969; C. louipaysani Pariselle \& Euzet, 1994; C. njinei Pariselle, Bilong Bilong \& Euzet, 2003; C. ornatus Pariselle \& Euzet, 1995; C. pouyaudi Pariselle \& Euzet, 1994; C. rognoni Pariselle, Bilong Bilong \& Euzet, 2003; C. sanjeani Pariselle \& Euzet, 1997; C. sclerosus Paperna \& Thurston, 1969; C. slembroucki Pariselle \& Euzet, 1998; C. tilapiae Paperna, 1960 and C. zambezensis Douëllou, 1993. Cichlidogyrus vandekerkhovei sp. nov. resembles closely C. rognoni by the morphology of the accessory piece. The new species can be easily distinguished from all these species by the length of the dorsal bar auricles, which are significantly longer (and see below, under C. makasai sp. nov.).

The specific epithet of the new species, vandekerkhovei, honours the aquatic ecologist Dr. Jochen Vandekerkhove (Belgium), in recognition of his guidance during the early research years of the junior author.

\section{Cichlidogyrus makasai sp. nov.}

\section{Fig. 4}

Type host: Ophthalmotilapia ventralis (Boulenger, 1898). Additional hosts: O. nasuta (Poll \& Matthes, 1962) and O. boops (Boulenger, 1901).

Site: gills.

Type locality: Wonzye Point $\left(8^{\circ} 43^{\prime} 30^{\prime \prime} S, 31^{\circ} 8^{\prime} 0^{\prime \prime} \mathrm{E}\right)$ (Lake Tanganyika, Zambia).

Other records: also found on the type host at Kasenga Point $\left(8^{\circ} 43^{\prime} 31^{\prime \prime}\right.$ S, 31 $\left.1^{\circ} 8^{\prime} 1^{\prime \prime} \mathrm{E}\right)$ (Zambia) and at Kikoti $\left(7^{\circ} 11^{\prime} 27^{\prime \prime}\right.$, $\left.30^{\circ} 4^{\prime} 0^{\prime \prime} \mathrm{E}\right)$ (Democratic Republic of the Congo), and on O. nasuta and $O$. boops at Mtosi $\left(7^{\circ} 35^{\prime} 27^{\prime \prime}\right.$, 30 30 38'29"E) (Tanzania) (all in Lake Tanganyika).

Material studied: 15 individuals.

Type material: holotype deposited at the Muséum National d'Histoire Naturelle (Paris): HEL 193, Tf 212. Paratypes deposited at the Muséum National d'Histoire Naturelle (Paris): HEL 194, Tf 213; at the Royal Museum for Central Africa (Tervuren): 37676-37677; and at the Iziko South African Museum (Cape Town): SAMCTA 29505a-b.

Description: Body 265 (211-321, $\mathrm{n}=15)$ long, 78 (62-109, $\mathrm{n}=15)$ wide at mid-body. Pharynx is $26(17-34, \mathrm{n}=9)$ wide. Dorsal anchor with very short shaft and more pronounced guard, blade arched: $\mathrm{a}=21(19-23, \mathrm{n}=21), \mathrm{b}=19(17-20, \mathrm{n}=21), \mathrm{c}=2$ $(1-2, \mathrm{n}=21), \mathrm{d}=6(4-8, \mathrm{n}=21), \mathrm{e}=9(8-10, \mathrm{n}=21)$. Dorsal transverse bar straight or slightly arched, small, with very long auricles: $\mathrm{x}=25(24-28, \mathrm{n}=15), \mathrm{y}=5(4-7, \mathrm{n}=13), \mathrm{w}=4(3-5, \mathrm{n}$ $=15), \mathrm{h}=20(17-23, \mathrm{n}=27)$. Ventral anchor, same size and shape as dorsal anchor: $\mathrm{a}=21(20-22, \mathrm{n}=21), \mathrm{b}=18(17-20, \mathrm{n}=$ $22), \mathrm{c}=1(1-3, \mathrm{n}=22), \mathrm{d}=6(5-8, \mathrm{n}=22), \mathrm{e}=8(7-10, \mathrm{n}=22)$. Ventral transverse bar V-shaped: $\mathrm{x}=29(25-33, \mathrm{n}=27), \mathrm{w}=3$ (2$4, \mathrm{n}=14)$. Uncinuli I small (see Remarks above) $=11(9-12, \mathrm{n}=$ 21) long; II = $10(9-15, \mathrm{n}=18)$ long; III to VII short (see Remarks below $)=14(11-17, \mathrm{n}=82)$ long. Penis beginning in a spherical bulb with pronounced heel, $\mathrm{He}=3(2-4 \mathrm{n}=15)$, a thin curved tube which tapers distally: $\mathrm{Pe}=73(69-79, \mathrm{n}=15)$, simple accessory piece slightly bent at distal third, resembles a spanner: Ap = $22(20-25, \mathrm{n}=15)$. Vagina not observed.

Remarks. Cichlidogyrus makasai sp. nov. belongs to the same morphological group of C. vandekerkhovei sp. nov. It can be easily distinguished from the latter species by the relatively longer auricles on the dorsal bar (smaller in C. makasai sp. nov. than in C. vandekerkhovei sp. nov.); the dorsal bar auricles are significantly longer than those of all other Cichlidogyrus spp. and shorter than those of Scutogyrus spp. (see Fig. 3). 


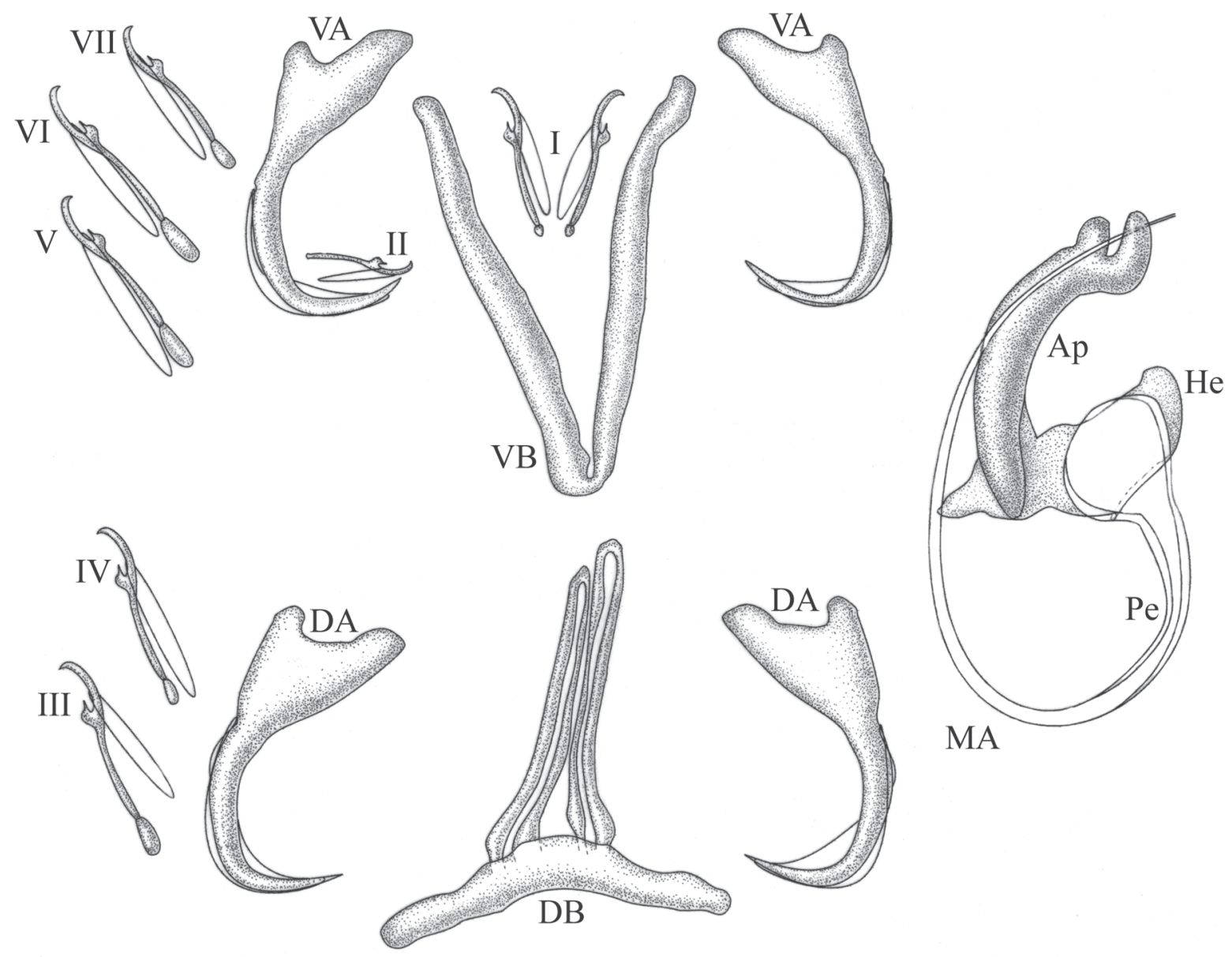

Figure 4. Cichlidogyrus makasai sp. nov.: (Ap) accessory piece; (DB) dorsal transverse bar; (DA) dorsal anchor; (He) heel; (MA) male apparatus; (Pe) penis; (VB) ventral transverse bar; (VA) ventral anchor; (I-VII) uncinuli. Scale bar $=30 \mu \mathrm{m}$.

Cichlidogyrus makasai sp. nov. is named after the research assistant Mr. Lawrence Makasa (Zambia), for his participation and contribution to the field expedition in Zambia and Tanzania during which most of the specimens for this study were collected.

\section{Cichlidogyrus centesimus sp. nov.} Fig. 5

Type host: Ophthalmotilapia ventralis (Boulenger, 1898). Additional hosts: O. nasuta (Poll \& Matthes, 1962) and O. boops (Boulenger, 1901).

Site: gills.

Type locality: Wonzye Point $\left(8^{\circ} 43^{\prime} 30^{\prime \prime} \mathrm{S}, 31^{\circ} 8^{\prime} 0^{\prime \prime} \mathrm{E}\right)$ (Lake Tanganyika, Zambia).

Other records: also found on the type host at Kasenga Point ( $\left.8^{\circ} 43^{\prime} 31^{\prime \prime} \mathrm{S}, 31^{\circ} 8^{\prime} 1^{\prime \prime} \mathrm{E}\right)$ (Zambia) and at Kikoti $\left(7^{\circ} 11^{\prime} 27^{\prime \prime} \mathrm{S}\right.$, $30^{\circ} 4^{\prime} 0^{\prime \prime} \mathrm{E}$ ) (Democratic Republic of the Congo), and on O. nasuta and $O$. boops at Mtosi $\left(7^{\circ} 35^{\prime} 27^{\prime \prime}\right.$ S, 30 38 $\left.29^{\prime \prime} \mathrm{E}\right)$ (Tanzania) (all in Lake Tanganyika).

Material studied: 18 individuals.

Type material: holotype deposited at the Muséum National d'Histoire Naturelle (Paris): HEL 195, Tf 214. Paratypes deposited at the Muséum National d'Histoire Naturelle (Paris): HEL 196, Tf 215; at the Royal Museum for Central Africa (Tervuren): 37678 and 37680, and at the Iziko South African Museum (Cape Town): SAMCTA 29506.

Description: Body 379 (263-520, $\mathrm{n}=16)$ long, 90 (59-147, $\mathrm{n}=15)$ wide at mid-body. Pharynx is $30(17-45, \mathrm{n}=8)$ wide. Large dorsal anchor with pronounced shaft and very long guard, blade arched: $\mathrm{a}=48(41-55, \mathrm{n}=31), \mathrm{b}=31(26-38, \mathrm{n}=30), \mathrm{c}=5$ $(3-10, \mathrm{n}=30), \mathrm{d}=19(13-24, \mathrm{n}=30), \mathrm{e}=9(7-12, \mathrm{n}=31)$. Thick dorsal transverse bar slightly arched: $\mathrm{x}=45(37-52, \mathrm{n}=17), \mathrm{y}=$ $19(16-22, \mathrm{n}=17), \mathrm{w}=8(7-10, \mathrm{n}=17), \mathrm{h}=13(11-16, \mathrm{n}=34)$. Large ventral anchor, with different shape and smaller size as compared to dorsal anchor, with well-developed guard and shaft, 


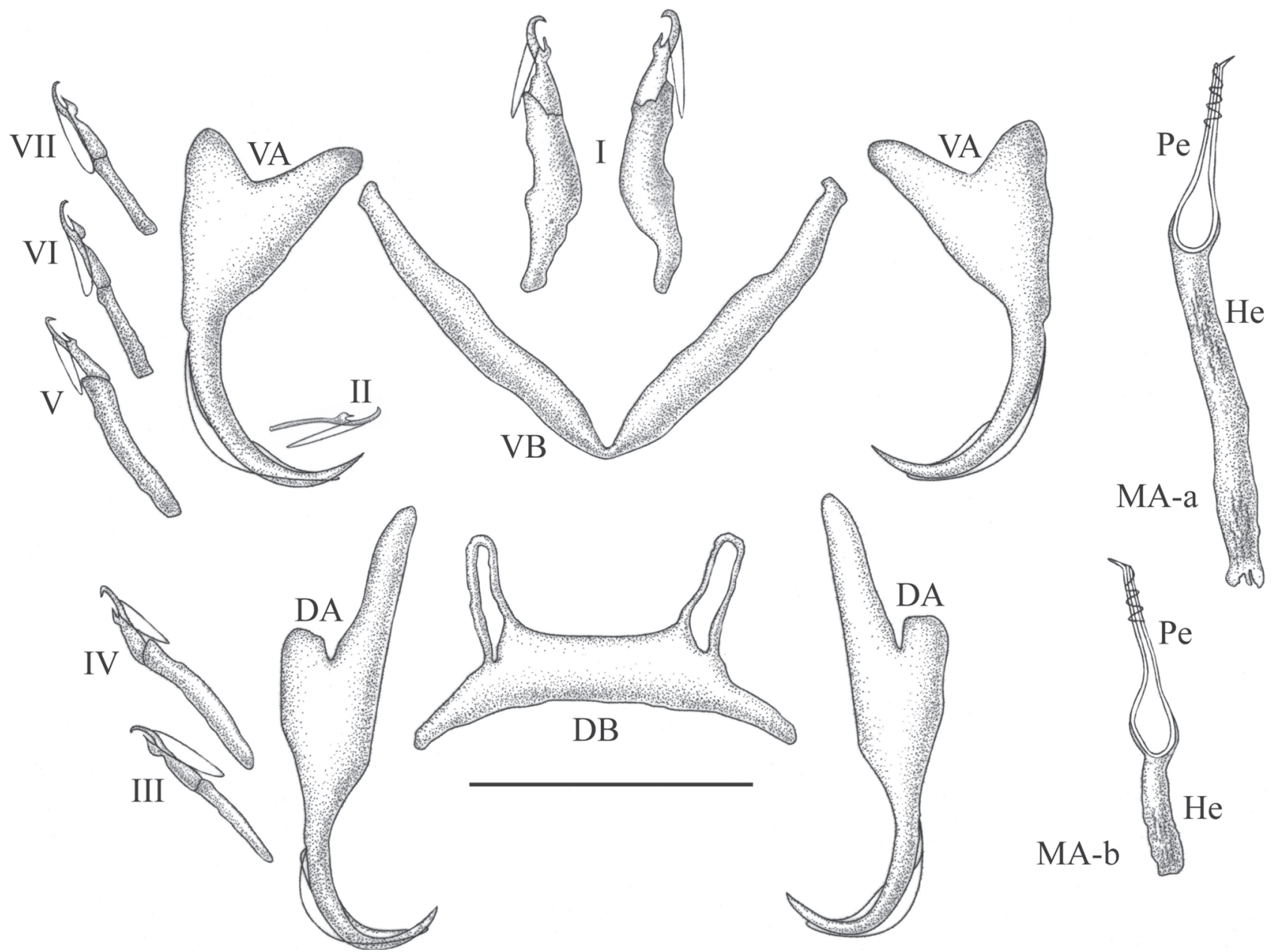

Figure 5. Cichlidogyrus centesimus sp. nov.: (DB) dorsal transverse bar; (DA) dorsal anchor; (He) heel; (MA-a) male apparatus, with long heel; (MA-b) male apparatus, with short heel; (Pe) penis; (VB) ventral transverse bar; (VA) ventral anchor; (I-VII) uncinuli. Scale bar = $30 \mu \mathrm{m}$.

blade regularly arched: $\mathrm{a}=38(34-44, \mathrm{n}=29), \mathrm{b}=36(32-41, \mathrm{n}=$ 29), $\mathrm{c}=5(3-10, \mathrm{n}=29), \mathrm{d}=10(5-14, \mathrm{n}=29), \mathrm{e}=11(9-13, \mathrm{n}=$ 29). Thick, long and $\mathrm{V}$-shaped ventral transverse bar: $\mathrm{x}=41$ (22$49, \mathrm{n}=35), \mathrm{w}=6(4-7, \mathrm{n}=18)$. Uncinuli I very large $=32(26-37$, $\mathrm{n}=35)$ long; II with larval size and shape II = $11(10-12, \mathrm{n}=24)$ long; III to VII long (see Remarks below) $=24(22-30, \mathrm{n}=135)$ long. Penis beginning in an ovoid bulb, with a straight and very long heel which is variable in length, $\mathrm{He}=24(11-47 \mathrm{n}=17)$, short and straight, the distal external wall marked with spirally coiled thickening forming 4/5 turns: $\mathrm{Pe}=24(23-25, \mathrm{n}=17)$, no accessory piece associated with the penis. Vagina not observed.

Remarks. The haptor of $C$. centesimus sp. nov. is unique because it shows long uncinuli I and III to VII (like $C$. arthracanthus Paperna, 1960 and C. inconsultans Birgi \& Lambert, 1986 (see Pariselle \& Euzet 2009). However, compared to these two species the pair I of uncinuli of the new species is larger and thicker, characteristics known only for species with short uncinuli pair III to VII such as C. albareti Pariselle \& Euzet, 1998; C. arfii Pariselle \& Euzet, 1995; C. berradae Pariselle \& Euzet, 2003; C. bychowskii (Markevich, 1934); C. dageti Dossou \& Birgi, 1984; C. digitatus Dossou, 1982; C. dionchus Paperna, 1968; C. euzeti Dossou \& Birgi, 1984; C. falcifer Dossou \& Birgi, 1984; C. halinus Paperna, 1969; C. longicirrus Paperna, 1965; C. nandidae Birgi \& Lambert, 1986; C. nuniezi Pariselle \& Euzet, 1998; C. papernastrema Price, Peebles \& Bamford, 1969; C. philander Douëllou, 1993; C. quaestio Douëllou, 1993; C. reversati Pariselle \& Euzet, 2003; C. sanseoi Pariselle \& Euzet, 2004; C. teugelsi Pariselle \& Euzet, 2004 and C. yanni Pariselle \& Euzet, 1996.

The male reproductive apparatus of $C$. centesimus sp. nov. is unique within Cichlidogyrus because 1) it lacks the accessory piece which is associated with the penis of all other Cichlidogyrus spp. known; 2) its penis displays a spirally coiled thickening (a feature observed in other Monogenea species such as Thaparocleidus chandpuri Pariselle, Lim \& Lambert, 2001). 
The length of the heel of the MCO is highly variable in C. centesimus but Principal Component Analysis (PCA) on all morphometric data detected no differences to warrant species delimitation (Fig. 6).

The specific name of C. centesimus (Latin for "one hundredth") refers to the fact that the species represents the one-hundredth species described by the senior author (A.P.).

Axis 3

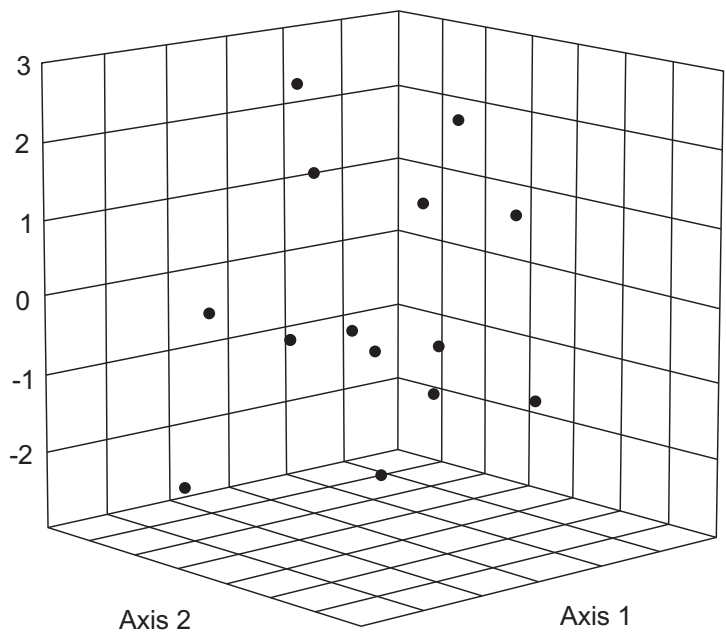

Figure 6. PCA (first three axes) on all measurements of $C$. centesimus sp. nov. showing no clusters.

\section{Cichlidogyrus sturmbaueri sp. nov.}

\section{Fig. 7}

Type host: Ophthalmotilapia ventralis (Boulenger, 1898). Additional host: O. nasuta (Poll \& Matthes, 1962).

Site: gills.

Type locality: Wonzye Point $\left(8^{\circ} 43^{\prime} 30^{\prime \prime}\right.$ S, $\left.31^{\circ} 8^{\prime} 0^{\prime \prime} \mathrm{E}\right)$ (Lake Tanganyika, Zambia).

Other records: also found on the type host at Kasenga Point ( $\left.8^{\circ} 43^{\prime} 31^{\prime \prime} \mathrm{S}, 31^{\circ} 8^{\prime} 1^{\prime \prime} \mathrm{E}\right)$ (Zambia) and on O. nasuta at

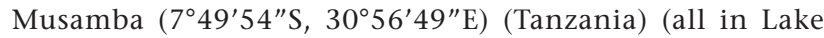
Tanganyika).

Material studied: 8 individuals.

Type material: holotype deposited at the Muséum National d'Histoire Naturelle (Paris): HEL 197, Tf 216. Paratypes deposited at the Muséum National d'Histoire Naturelle (Paris): HEL 198, Tf 217; at the Royal Museum for Central Africa (Tervuren): 37681-37682; and at the Iziko South African Museum (Cape Town): SAMCTA 29507.

Description: Body 311 (259-366, n = 7) long, 83 (63-115, $\mathrm{n}=7)$ wide at mid-body. Pharynx is $27(17-42, \mathrm{n}=6)$ wide. Dorsal anchor small with pronounced shaft and guard: $\mathrm{a}=20$ $(19-21, \mathrm{n}=12), \mathrm{b}=17(16-20, \mathrm{n}=12), \mathrm{c}=3(2-3, \mathrm{n}=12), \mathrm{d}=7$ $(5-7, \mathrm{n}=12), \mathrm{e}=8(6-9, \mathrm{n}=12)$. Dorsal transverse bar thin and arched: $\mathrm{x}=23(20-28, \mathrm{n}=8), \mathrm{y}=10(9-11, \mathrm{n}=8), \mathrm{w}=4(3-4, \mathrm{n}$ $=8), \mathrm{h}=13(12-15, \mathrm{n}=16)$. Ventral anchor similar to dorsal anchor, but slightly larger: $\mathrm{a}=24(23-26, \mathrm{n}=12), \mathrm{b}=20(18-21$, $\mathrm{n}=12), \mathrm{c}=3(2-5, \mathrm{n}=12), \mathrm{d}=9(7-10, \mathrm{n}=12), \mathrm{e}=8(7-11, \mathrm{n}=$ $12)$. V-shaped and thin ventral transverse bar: $\mathrm{x}=34(31-39, \mathrm{n}$ $=16), \mathrm{w}=4(3-4, \mathrm{n}=8)$. Uncinuli I short $=14(13-16, \mathrm{n}=12)$ long; II with larval size and shape II = $11(10-12, \mathrm{n}=7)$ long; III to VII long = $22(19-24, \mathrm{n}=23)$ long. Penis beginning in an ovoid bulb, with short heel, $\mathrm{He}=6(4-7 \mathrm{n}=8)$, straight: $\mathrm{Pe}=36$ $(34-39, \mathrm{n}=8)$, h-shaped accessory piece associated with the penis, $A p=25$ (24-28). Vagina not observed.

Remarks. The haptoral sclerites of $C$. sturmbaueri sp. nov. belongs to the group with short uncinuli I and long uncinuli III to VII such as C. aegypticus Ergens, 1981; C. agnesi Pariselle \& Euzet, 1994; C. anthemocolpos Dossou, 1982; C. bilongi Pariselle \& Euzet, 1996; C. bonhommei Pariselle \& Euzet, 1998; C. bouvii Pariselle \& Euzet, 1997; C. dossoui Douëllou, 1993; C. douellouae Pariselle, Bilong Bilong \& Euzet, 2003; C. ergensi Dossou, 1982; C. flexicolpos Pariselle \& Euzet, 1995; C. gallus Pariselle \& Euzet, 1995; C. guirali Pariselle \& Euzet, 1997; C. hemi Pariselle \& Euzet, 1998; C. kouassii N'Douba, Thys van den Audenaerde \& Pariselle, 1997; C. legendrei Pariselle \& Euzet, 2003; C. lemoallei Pariselle \& Euzet, 2003; C. microscutus Pariselle \& Euzet, 1996; C. ouedraogoi Pariselle \& Euzet, 1996; C. paganoi Pariselle \& Euzet, 1997; C. testificatus Dossou, 1982; C. thurstonae Ergens, 1981; C. tiberianus Paperna, 1960 and C. vexus Pariselle \& Euzet, 1995. Cichlidogyrus sturmbaueri sp. nov. is unique since it exhibits a h-shaped accessory piece.

The specific epithet, sturmbaueri, is given in honour of Prof. Christian Sturmbauer (Austria), specialist in the evolution of Tanganyika cichlids and team leader of the expedition in Zambia and Tanzania during which most of the host fish used in this study was caught.

\section{DISCUSSION}

Four new representatives of Cichlidogyrus, C. vandekerkhovei sp. nov., C. makasai sp. nov., C. centesimus sp. nov. and $C$. sturmbaueri sp. nov. are described from Ophthalmotilapia cichlids. The host species are members of the endemic Tanganyika cichlid tribe Ectodini (Poll 1986). Although ancyrocephalids are known to be a speciose lineage of parasites of cichlids (PARISELLE \& EUZET 2009) and that Lake Tanganyika is a well-established diversity hotspot of Cichlidae (see SNOEKs 2000), these descriptions represent the first records of Ancyrocephalidae and only the second of Monogenea in this basin (VANHove et al. 2011).

The four species described herein belong to three different morphological groups of Cichlidogyrus (Pariselle \& Euzet 2003, 2009, Vignon et al. 2011). Cichlidogyrus centesimus sp. nov. displays a hitherto unknown combination of characters (and the absence of an accessory piece in the MCO could even indicate the need to revise the generic diagnosis). Hence, based on haptor characteristics, the studied species of Ophthalmotilapia 


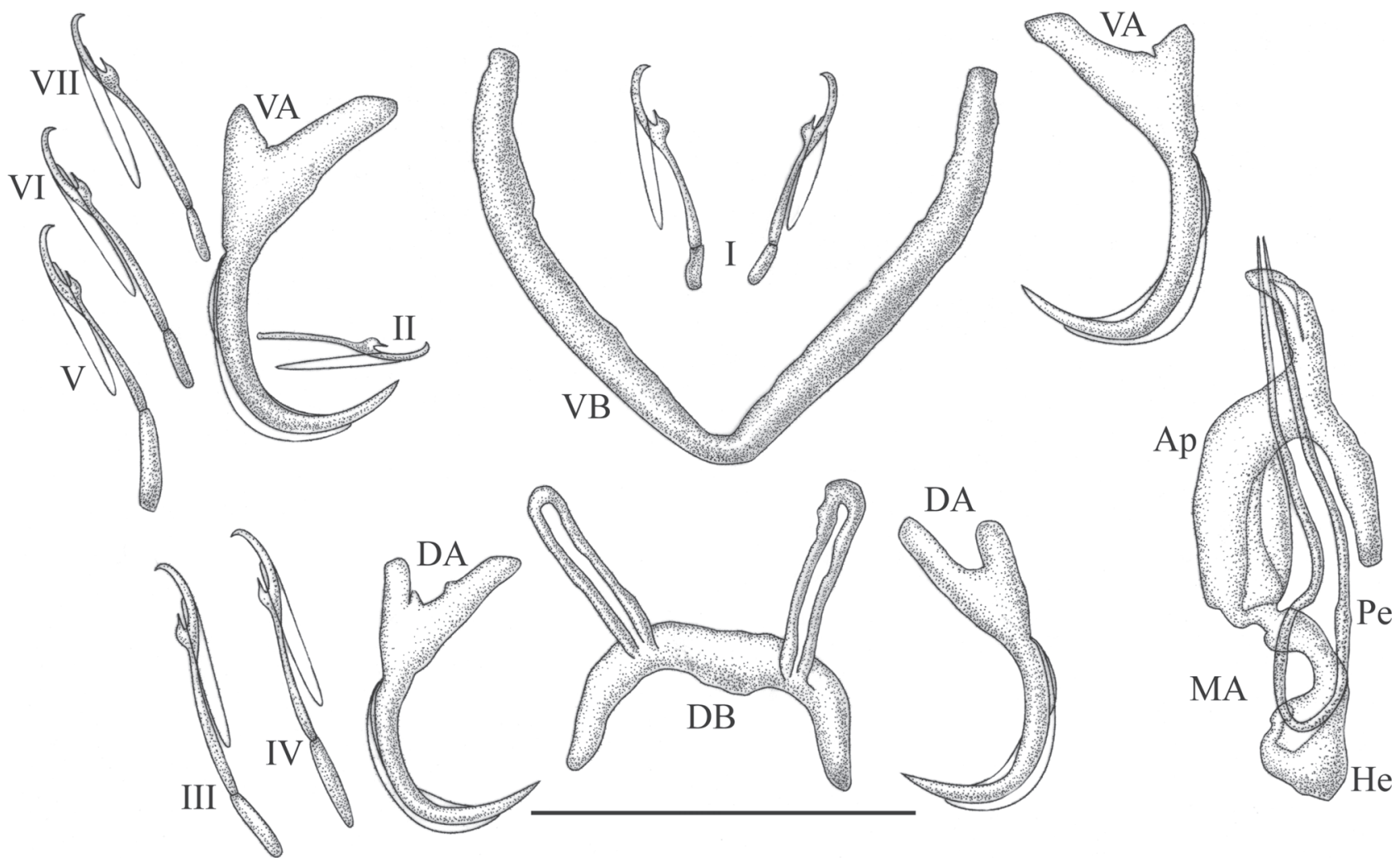

Figure 7. Cichlidogyrus sturmbaueri sp. nov.: (Ap) accessory piece; (DB) dorsal transverse bar; (DA) dorsal anchor; (He) heel; (MA) male apparatus; (Pe) penis; (VB) ventral transverse bar; (VA) ventral anchor; (I-VII) uncinuli. Scale bar $=30 \mu \mathrm{m}$.

are host to a remarkable diversity of Cichlidogyrus - not in terms of species richness, but in terms of the various morphological groups within Cichlidogyrus co-occurring on one individual host species. Pouyaud et al. (2006) suggest that the haptor characteristics are phylogenetically informative to distinguish groups of Cichlidogyrus spp., while the genital morphology is more appropriate for species identification.

In view of the current lack of genetic data and comparative material of Cichlidogyrus spp. from the Tanganyika basin, it is impossible to estimate to what extent the current diversity in haptor morphology actually represents the presence of distinct lineages of Monogenea. Thus, it is not yet appropriate to infer evolutionary scenarios on the origins of the species under study. Rather, we suggest some issues that might deserve closer attention when looking into the parasite diversity on species of Ophthalmotilapia or in the entire basin.

The vagility of the host species is a factor that may potentially influence parasite species richness (GREGory 1990, Mwita \& Nkwengulila 2008). As O. ventralis is a good disperser, leading to rather unrestrained gene flow (SEFC et al. 2007), it might be interesting to compare its helminth community to the corresponding fauna of host species displaying small-scale geographic population structuring or phylopatric behaviour.
Furthermore, the unique ecosystem characteristics of Lake Tanganyika also offer opportunities for a high richness of fish parasites. For instance, ecological stability and depth of the lake facilitate its role as an evolutionary reservoir, such as observed for thalassoid gastropods (WILSON et al. 2004) and cichlids (Nishida 1991, Salzburger et al. 2002). Therefore, the monogenean community might, partly, consist of ancient lineages as well. Furthermore, KoblmülLeR et al. (2006) suggest that the divergence of hosts belonging to the Tropheini influenced differentiation and led to an accelerated rate of molecular evolution of the brood parasite Synodontis multipunctata Boulenger, 1898 (cuckoo catfish) from Lake Tanganyika. Hence, the role of the radiation of Cichlidae in the (co-)evolutionary dynamics of species of Cichlidogyrus should also be considered.

Finally, we want to indicate that the species under study, $O$. ventralis, apparently shares several parasite species with its congeners, O. boops and O. nasuta. These species of Ophthalmotilapia, although, do not compose a monophyletic group (KoblmülLer et al. 2004). An apparently broad host spectrum in Cichlidogyrus or other representatives of the Monogenea may be the result of cryptic speciation (ZiĘTARA \& Lumme 2002, HuYse \& Malmberg 2004, Pouyaud et al. 2006, Kuusela et al. 2008). Consequently, studies on the new parasite species, based on molecular 
data, are needed, not only to estimate the extent to which the distinct haptor morphology reflects the existence of various lineages but also to check for possible cryptic speciation leading to an underestimated host-specificity. Furthermore, parasite data from other cichlids in the Tanganyika basin are necessary to formulate hypotheses on the origin and evolutionary history of this seemingly very diverse fauna of monogenean flatworms.

\section{ACKNOWLEDGEMENTS}

M.P.M.V. is partly hosted by the Ichthyology Unit, African Zoology Department, Royal Museum for Central Africa (Tervuren, Belgium). T. Huyse (K.U.Leuven) and J. Snoeks (RMCA and K.U.Leuven) provided valuable contributions to this research and access to lab and collection facilities; M. Parrent (RMCA) provided technical assistance; L. Meslin (ISE-M) helped with drawings; and M. Van Steenberge (RMCA and K.U.Leuven) offered useful discussions on the fish hosts. C. Sturmbauer (Karl-Franzens University of Graz) organized the expedition during which many of the specimens were collected and identificatied hosts. We are indebted to C. Gillardin (ZAVO), J.K. Zimba, L. Makasa (Lake Tanganyika Research Station, Department of Fisheries, Ministry of Agriculture and Co-operatives, Mpulungu, Zambia), T. Veall, O.R. Mangwangwa (Rift Valley Tropicals, Zambia/Tanzania), M. Nshombo, N. Mulimbwa, R. Muzumani, B. Muterezi, N. Mbirize, L. Kapepula (Centre de Recherche en Hydrobiologie, Uvira, DRC), C. Katongo (University of Zambia, Lusaka) and their technical staff, for scientific, logistical and administrative contributions to the fieldwork. The Tanzania Commission for Science and Technology (COSTECH) granted the research permit no. 2007-258-CC-2006-151 to M.P.M.V. M.P.M.V. is recipient of a PhD-fellowship of the Research Foundation - Flanders (FWO - Vlaanderen). The fieldwork for this study was funded by two travel grants from the Research Foundation - Flanders and one from the King Leopold III Fund for Nature Conservation and Exploration, to M.P.M.V. W.A. Boeger (Universidade Federal do Paraná, Curitiba, Brazil), as well as two anonymous referees, contributed to improve this study.

\section{LITERATURE CITED}

BakKe, T. A.; P. Harris \& J. Cable. 2002. Host specificity dynamics: observations on gyrodactylid monogeneans. International Journal for Parasitology 32: 281-308.

Barson, M.; I. Přikrylová; M.P.M. Vanhove \& T. Huyse. 2010. Parasite hybridization in African Macrogyrodactylus spp. (Monogenea, Platyhelminthes) signals historical host distribution. Parasitology 137 (10): 1585-1595.

BATES, J.W. 1997. The slide-sealing compound "Glyceel". Journal of Nematology 29 (4): 565-566.

Brown, K.J.; L. RÜBER; R. Bills \& J.J. DAY. 2010. Mastacembelid eels support Lake Tanganyika as an evolutionary hotspot of diversification. BMC Evolutionary Biology 10: 188.
Cohen, A.S.; K.E. Lezzar; J.J. Tiercelin \& M. Soreghan. 1997. New palaeogeographic and lake-level reconstructions of Lake Tanganyika: implications for tectonic, climatic and biological evolution in a rift lake. Basin Research 9: 107-132.

DAY, J.J. \& M. WILKINSON. 2006. On the origin of the Synodontis catfish species flock from Lake Tanganyika. Biology Letters 2: 548-552.

Euzet, L. \& M. Prost. 1981. Report of the meeting on Monogenea: problems of systematics, biology and ecology, p. 1003-1004. In: W. SLUSARSKI (Ed.). Review of advances in parasitology. Warsaw, P.W.N. Polish Scientific Publishers, 1119p.

Euzet, L.; J.-F. Agnèse \& A. Lambert. 1989. Valeur des parasites comme critère d'identification de l'espèce hôte. Démonstration convergente par l'étude parasitologique des Monogènes branchiaux et l'analyse génétique des poissons hôtes. Compte Rendu de l'Académie des Sciences de Paris 308: 385-388.

Galis, F. \& J.A.J. Metz. 1998. Why are there so many cichlid species? Trends in Ecology \& Evolution 13: 1-2.

Gregory, R.D. 1990. Parasites and host geographic range as illustrated by waterfowl. Functional Ecology 4: 645-654.

GuÉgan, J.-F. \& A. Lambert. 1990. Twelve new species of dactylogyrids (Platyhelminthes, Monogenea) from West African barbels (Teleostei, Cyprinidae), with some biogeographical implications. Systematic Parasitology 17: 153-181.

Gussev, A.V. 1962. Order Dactylogyridea, p. 204-342. In: I.E. Bychovskaya-Pavlovskaya; A.V. Gussev; M.N. Dubinina; N.A. Izymova; T.S. Smirnova; I.L. Sokolovskaya; G.A. Shtein; S.S. SHUL'MAN \& V.M. EPSTHEIN (Eds). Key to the parasites of freshwater fish of the USSR. Jerusalem (1964), Israel Program for Scientific Translations, 919p. [Russian original: Opredelitel' parazitov presnovohnyh ryb SSSR. MoscowLeningrad: Izadtel'stovo Akademii Nauk SSSR, 776 p.]

Hanssens, M.; J. Snoeks \& E. Verheyen. 1999. A morphometric revision of the genus Ophthalmotilapia (Teleostei, Cichlidae) from Lake Tanganyika (East Africa). Zoological Journal of the Linnean Society 125: 487-512.

Huyse, T. \& G. Malmberg. 2004. Molecular and morphological comparisons between Gyrodactylus ostendicus n. sp. (Monogenea: Gyrodactylidae) on Pomatoschistus microps (Krøyer) and G. harengi Malmberg, 1957 on Clupea harengus membras L. Systematic Parasitology 58: 105-113.

Huyse, T.; C. Pampoulie; V. Audenaert \& F.A.M. Volckaert. 2006. First report of Gyrodactylus spp. (Platyhelminthes: Monogenea) in the Western Mediterranean Sea: molecular and morphological descriptions. Journal of Parasitology 92: 682-690.

Koblmüller, S.; W. SAlzburger \& C. Sturmbauer. 2004. Evolutionary relationships in the sand-dwelling cichlid lineage of Lake Tanganyika suggest multiple colonization of rocky habitats and convergent origin of biparental mouthbrooding. Journal of Molecular Evolution 58: 79-96. doi: 10.1007/s00239-0032527-1. 
Koblmüller, S.; C. Sturmbauer; E. Verheyen; A. Meyer \& W. Salzburger. 2006. Mitochondrial phylogeny and phylogeography of East African squeaker catfishes (Siluriformes: Synodontis). BMC Evolutionary Biology 6: 49. doi: 10.1186/1471-2148-6-49.

Koblmüller, S.; K.M. Sefc \& C. Sturmbauer. 2008. The Lake Tanganyika cichlid species assemblage: recent advances in molecular phylogenetics. Hydrobiologia 615: 5-20.

Konings, A. 1998. Tanganyika cichlids in their natural habitat. El Paso, Cichlid Press, 272p.

Kuusela, J.; M.S. Ziętara \& J. Lumme. 2008. Description of three new European cryptic species of Gyrodactylus Nordmann, 1832 supported by nuclear and mitochondrial phylogenetic characterization. Acta Parasitologica 53: 120-126.

Malmberg, G. 1957. On the occurrence of Gyrodactylus on Swedish fishes. Skrifter utgivna av Södra Sveriges Fiskeriföreningen: 19-76.

Marijnissen, S.A.E.; E. Michel; S.R. Daniels; D. Erpenbeck; S.B.J. Menken \& F.R. Schram. 2006. Molecular evidence for recent divergence of Lake Tanganyika endemic crabs (Decapoda: Platythelphusidae). Molecular Phylogenetics and Evolution 40: 628-634.

MaRTENS, K. \& I. SCHÖN. 1999. Crustacean biodiversity in ancient lakes: a review. Crustaceana 72 (8): 899-910.

Michel, E.; J.A. Todd; D.F.R. Cleary; I. Kingma; A.S. Cohen \& M.J. GENNER. 2004. Scales of endemism: challenges for conservation and incentives for evolutionary studies in a gastropod species flock from Lake Tanganyika. Journal of Conchology Special Publication 3: 155-172.

Mwita, C. \& G. Nkwengulila. 2008. Determinants of the parasite community of clariid fishes from Lake Victoria, Tanzania. Journal of Helminthology 82: 7-16.

Nieberding, C.M. \& I. Olivieri. 2007. Parasites: proxies for host genealogy and ecology? Trends in Ecology and Evolution 22 (3): 156-165.

NisHIDA, M. 1991. Lake Tanganyika as an evolutionary reservoir of old lineages of East African cichlid fishes: inferences from allozyme data. Cellular and Molecular Life Sciences 47 (9): 974-979.

PAPERNA, I. 1960. Studies on Monogenetic Trematodes in Israel. 2 Monogenetic Trematodes of Cichlids. Bamidgeh, Bulletin of Fish Culture in Israel 12: 20-33.

Pariselle, A. \& L. Euzet. 1995a. Scutogyrus gen. n. (Monogenea, Ancyrocephalidae) for Cichlidogyrus longicornis minus Dossou, 1982, C. l. longicornis, and C. l. gravivaginus Paperna \& Thurston, 1969, with description of three new species parasitic on African cichlids. Journal of the Helminthological Society of Washington 62: 157-173.

Pariselle, A. \& L. Euzet. 1995b. Gill parasites of the genus Cichlidogyrus Paperna, 1960 (Monogenea, Ancyrocephalidae) from Tilapia guineensis (Bleeker, 1862), with descriptions of six new species. Systematic Parasitology 30: 187-198.

Pariselle, A. \& L. Euzet. 2003. Four new species of Cichlidogyrus (Monogenea: Ancyrocephalidae), gill parasites of Tilapia cabrae (Teleostei: Cichlidae), with discussion on relative length of haptoral sclerites. Folia Parasitologica 50: 195201.

Pariselle, A. \& L. Euzet. 2009. Systematic revision of dactylogyridean parasites (Monogenea) from cichlid fishes in Africa, the Levant and Madagascar. Zoosystema 31 (4): 849898.

Pariselle, A.; C. Bilong Bilong \& L. Euzet 2003a. Four new species of Cichlidogyrus Paperna, 1960 (Monogenea, Ancyrocephalidae), all gill parasites from African mouthbreeder tilapias of the genera Sarotherodon and Oreochromis (Pisces, Cichlidae), with a redescription of C. thurstonae Ergens, 1981. Systematic Parasitology 56: 201-210.

Pariselle A.; S. Morand; M.R. Deveney \& L. Pouyaud. 2003b. Parasite species richness of closely related hosts: historical scenario and "genetic" hypothesis, p. 147-166. In: C. Combes \& J. Jourdan (Eds.). Hommage à Louis Euzet - Taxonomie, écologie et évolution des métazoaires parasites. Taxonomy, ecology and evolution of metazoan parasites. Perpignan, Les Presses Universitaires de Perpignan, $380+396$ p.

Paugy, D.; J.-F. Guégan \& J.-F. Agnèse. 1990. Three simultaneous and independent approaches to the characterization of a new species of Labeo (Teleostei, Cyprinidae) from West Africa. Canadian Journal of Zoology 68: 1124-1131.

Plaisance, L.; V. Rousset; S. Morand \& D.T.J. Littlewood. 2008. Colonization of pacific islands by parasites of low dispersal abilities: phylogeography of two monogenean species parasitizing butterflyfishes in the Indo-West Pacific Ocean. Journal of Biogeography 35: 76-87.

Poll, M. 1986. Classification des Cichlidae du lac Tanganika. Tribus, genres et espèces. Mémoires de la Classe des Sciences XLV. Brussels, Académie Royale de Belgique, $2^{\text {nd }}$ ed., 163p.

Pouyaud, L.; E. Desmarais; M. Deveney \& A. Pariselle. 2006. Phylogenetic relationships among monogenean gill parasites (Dactylogyridae, Ancyrocephalidae) infesting tilapiine hosts (Cichlidae): systematic and evolutionary implications. Molecular Phylogenetics and Evolution 38: 241-249.

Salzburger, W.; A. Meyer; S. Baric; E. Verheyen \& C. Sturmbauer. 2002. Phylogeny of the Lake Tanganyika cichlid species flock and its relationship to the Central and East African haplochromine cichlid fish faunas. Systematic Biology 51: 113-135.

Sefc, K.M.; S. Baric; W. Salzburger \& C. Sturmbauer. 2007. Speciesspecific population structure in rock-specialized sympatric cichlid species in Lake Tanganyika, East Africa. Journal of Molecular Evolution 64: 33-49.

SnOEks, J. 2000. How well known is the ichthyodiversity of the large East African lakes? Advances in Ecological Research 31: 17-38.

STATSOFt, Inc. 2009. STATISTICA (Data Analysis Software System), Version 9.0. www.statsoft.com. 
TAKAHASHI, T. 2003. Systematics of Tanganyikan cichlid fishes (Teleostei: Perciformes). Ichthyological Research 50: 367-382.

Van Every, L.R. \& D.C. Kritsky. 1992. Neotropical Monogenoidea. 18. Anacanthorus Mizelle and Price, 1965 (Dactylogyridae, Anacanthorinae) of piranha (Characoidea, Serrasalmidae) from the Central Amazon, their phylogeny, and aspects of host-parasite coevolution. Journal of the Helminthological Society of Washington 59: 52-75.

Vanhove, M.P.M.; J. Snoeks; F.A.M. Volckaert \& T. Huyse. 2011. First description of monogenean parasites in Lake Tanganyika: the cichlid Simochromis diagramma (Teleostei, Cichlidae) harbours a high diversity of Gyrodactylus species (Platyhelminthes, Monogenea). Parasitology 138 (3): 364-380 (erratum in 138: 403). doi:10.1017/S0031182010001356.

Vignon, M.; A. Pariselle \& M.P.M. Vanhove. 2011. Modularity in attachment organs of African Cichlidogyrus (Platyhelminthes, Monogenea, Ancyrocephalidae) reflects phylogeny rather than host specificity or geographic distribution. Biological Journal of the Linnean Society 102 (3): 694-706.
Vreven, E.J. \& J. Snoeks. 2009. A new mastacembelid species from Lake Tanganyika: a case of complex evolutionary history. Journal of Fish Biology 75: 1018-1047.

WhitTington, I.D. 1998. Diversity "down under": monogeneans in the Antipodes (Australia) with a prediction of monogenean biodiversity worldwide. International Journal for Parasitology 28 (10): 1481-1493.

Wilson, A.B.; M. Glaubrecht \& A. Meyer. 2004. Ancient lakes as evolutionary reservoirs: evidence from the thalassoid gastropods of Lake Tanganyika. Proceedings of the Royal Society of London Series B - Biological Sciences 271: 529536.

Wouters, K. \& K. Martens. 2001. On the Cyprideis species flock (Crustacea, Ostracoda) in Lake Tanganyika, with the description of four new species. Hydrobiologia 450: 111127.

Ziętara, M.S. \& J. Lumme. 2002. Speciation by host-switching and adaptive radiation in a fish parasite genus Gyrodactylus (Monogenea, Gyrodactylidae). Evolution 56: 2445-2458.

Submitted: 29.X.2010; Accepted: 27.II.2011.

Editorial responsibility: Marcus V. Domingues 